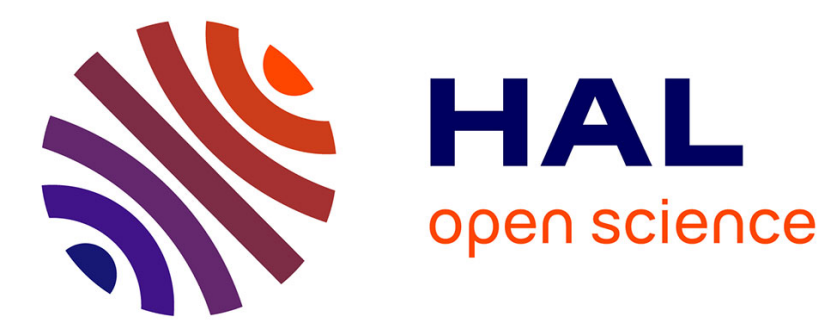

\title{
An operational flood warning system for poorly gauged basins. Demonstration in the Guadalhorce basin (Spain).
}

Pierre-Antoine Versini, Marc Berenguer, Carles Corral, Daniel Sempere-Torres

\section{To cite this version:}

Pierre-Antoine Versini, Marc Berenguer, Carles Corral, Daniel Sempere-Torres. An operational flood warning system for poorly gauged basins. Demonstration in the Guadalhorce basin (Spain).. Natural Hazards, 2014, 71 (3), pp.1355-1378. 10.1007/s11069-013-0949-7 . hal-01080252

\section{HAL Id: hal-01080252 https://hal.science/hal-01080252}

Submitted on 17 May 2015

HAL is a multi-disciplinary open access archive for the deposit and dissemination of scientific research documents, whether they are published or not. The documents may come from teaching and research institutions in France or abroad, or from public or private research centers.
L'archive ouverte pluridisciplinaire HAL, est destinée au dépôt et à la diffusion de documents scientifiques de niveau recherche, publiés ou non, émanant des établissements d'enseignement et de recherche français ou étrangers, des laboratoires publics ou privés. 


\section{An operational flood warning system for 2 poorly gauged basins. Demonstration in the 3 Guadalhorce basin (Spain)}

4

P.-A. Versini ${ }^{1,2}$, M. Berenguer ${ }^{1}$, C. Corral ${ }^{1}$, D. Sempere-Torres ${ }^{1}$

[1] Centre de Recerca Aplicada en Hidrometeorologia, Barcelona, Spain

[2] Laboratoire Eau Environnemnent et Systèmes Urbains, Ecole Nationale des Ponts et Chaussées, France

Correspondence to: P.-A. Versini (pierre-antoine.versini@leesu.enpc.fr)

\section{Abstract}

This paper deals with the presentation of a flood warning system (GFWS) developed for the specific characteristics of the Guadalhorce basin $\left(3200 \mathrm{~km}^{2}\right.$, SE of Spain), which is poorly gauged and often affected by flash and plain floods Its complementarity with the European Flood Alert System (EFAS) has also been studied. At a lower resolution, EFAS is able to provide a flood forecast several days in advance.

The GFWS is adapted to the use of distributed rainfall maps (such as radar rainfall estimates) and discharge forecasts are computed using a distributed rainfall-runoff model. Due to the lack of flow measurements, the model parameters calibrated on a small watershed have been transferred in most of the basin area. The system is oriented to provide distributed warnings and fulfils the requirements of ungauged basins.

This work reports on the performance of the system on two recent rainfall events which caused several inundations. These results show how the GFWS performed well and was able to forecast the location and timing of flooding. It demonstrates that despite its limitations, a simple rainfall-runoff model and a relatively simple calibration could be useful for event risk management. Moreover, with low resolution and long anticipation, EFAS appears as a good complement tool to improve flood forecasting and compensate for the short lead times of the GFWS. 


\section{Introduction}

35 Floods represent the most serious natural hazard in Europe, and flood management is a 36 critical component of public safety (Hajat et al. 2003; Barredo, 2007). During the last 50

37 years significant efforts to improve flood warning systems (FWS) have been carried out by 38 the scientific, technical and administration sectors. Thus in the context of medium to large 39 river basins, with response times of the order of tens of hours, forecasts, warnings and 40 public preparedness for reducing casualties from extreme plain floods have clearly 41 improved (Meon 2006). However, the achievements for forecasting flash floods, 42 characterized by short-lasting storms affecting reduced areas of a watershed, have been less 43 impressive. As flood forecasting is in many countries limited to the main streams or to 44 specific watersheds with particular assets like hydropower dams, which are in most cases 45 well-gauged river sections, it leaves large parts of the territory not covered by flood 46 monitoring networks (see for instance: Borga et al. 2007; Costa and Jarett 2008; Gaume et 47 al. 2009).

48 A major concern in the context of FWS operating in basins prone to flash floods is to 49 monitor the variability of rainfall in space and time. In particular, the use of radar-based 50 quantitative precipitation estimates (QPE) and nowcasts has been demonstrated to be an 51 interesting tool for anticipating and quantifying the consequences of rainfall at the ground. 52 Radar products are particularly interesting in areas frequently affected by severe storms 53 with complex spatio-temporal patterns (of tens of $\mathrm{km}^{2}$ ) and response times of the order of 54 tens of minutes to few hours (see for instance: Sempere-Torres et al. 1999; Berenguer et al. 55 2005; Berne et al. 2005; Borga et al. 2006; Germann et al. 2009).

56 The use of distributed rainfall-runoff models represents a second key element in the 57 production of distributed flow forecasts. Distributed models in general do not seem to 58 perform significantly better than classic simple lumped models when they are used to

59 forecast the discharges at a few specific points of gauged watersheds, although this topic is 60 still a matter of discussion (e.g. Carpenter and Georgakakos 2006; Reed et al. 2004).

61 However they provide much richer information than lumped models as they are able to 62 consider the spatial distribution of model inputs (in particular, rainfall) and/or parameters, 63 and produce distributed runoff simulations. In the case of ungauged watersheds, 
64 regionalization techniques (see for example Blöschl and Sivapalan 1995) are frequently 65 used to extrapolate model parameters estimated from closest gauged catchment.

66 In this context, two types of warnings can be delivered in the framework of FWS: (i) 67 warnings based on rainfall measurements, and (ii) warnings based on simulated discharges. 68 Both have advantages and limitations.

69 Basically, warnings based on rainfall can be delivered by comparing precipitation 70 accumulations (on different time) to a corresponding reference associated to a probability 71 of occurrence and a return period. As soil moisture condition is not taken into account, the 72 results can sometimes be very different to those based on hydrological simulations (see 73 Alfieri et al. 2011). A another well-known approach to issuing warnings based on rainfall is 74 the Flash Flood Guidance, FFG (Georgakakos 2006). The FFG computes the amount of 75 rainfall of a given duration required to cause flooding in a certain basin. If the 76 corresponding observed or forecasted rainfall amounts (integrated for the same duration 77 within the basin) exceeds the pre-computed threshold, a flood warning is issued. The FFG 78 represents a first attempt to evaluate the potential flooding and can be employed at different 79 time and scale resolutions (Norbiato et al. 2008). It requires information on the antecedent 80 soil moisture conditions, but does not explicitly compute the discharge responsible for 81 flooding.

82 Alternatively, FWSs may use rainfall-runoff model to issue warnings based on explicit 83 discharge simulations and forecasts. They run at different resolutions depending on the 84 characteristics of the floods that are to be forecasted. Covering whole Europe with a spatial 85 resolution of $5 \mathrm{~km}$, the European Flood Alert System (EFAS, Thielen et al. 2009) aims at 86 alerting for floods in trans-national European river basins up to 10 days in advance using 87 model inputs generated with an ensemble weather prediction system. At regional scale, 88 there are several operational FWSs based on discharge simulations. Some examples can be 89 cited: AIGA run by Meteo France ${ }^{1}$ in the south-east of France (Lavabre and Gregoris 90 2006), EHIMI run by $\mathrm{ACA}^{2}$ in Catalonia (Corral et al. 2009) and PREVAH, run by $\mathrm{WSL}^{3}$

\footnotetext{
1 French Meteorological Agency

2 Catalan Water Agency
} 
91 in Switzerland (Viviroli et al. 2009). Further work is still under development and not yet

92 operational (Reed et al. 2007; Javelle et al. 2010 for example). Note these regional models

93 can be aggregated at the national scale as the UK National Flood Forecasting System

94 (NFFS) or VIGICRUES run by $\mathrm{SCHAPI}^{4}$ in France (Tanguy et al. 2005). Although they

95 are devoted to a limited area, these regional systems are run at higher resolutions and,

96 consequently, they are more adapted to forecast flash floods. These FWSs are generally

97 based on a similar scheme: the distributed rainfall-runoff model is run to simulate the

98 discharges in several locations of the basin, and these are compared to a database of pre-

99 established flow thresholds to quantify the hazard at each location. A warning is issued

100 when the simulated discharges exceed certain thresholds. The advantage of this method is

101 the use of a discharge value to assess flood hazard. The main weakness generally related to

102 discharge simulation is that model calibration requires stream gauges distributed over the

103 watershed and available historical time series for its calibration.

104 Based on these considerations, a real-time FWS was implemented in 2009 in the

105 Guadalhorce basin (Andalusia, Spain) in collaboration with regional stakeholders interested

106 in flood warning. The main objective was to operationally deliver spatially-distributed early

107 flood warnings, as a tool to raise the awareness of rescue services and increase their

108 preparedness. To suit the short response time and high space resolution required for

109 operational management of this basin, a specific and local FWS (referred to as GFWS

110 hereafter) has been developed. The main challenge the GFWS had to face was the scarcity

111 of stream gauges and the lack of historical hydrometeorological data. In part to overcome

112 this situation, we chose to explore the two approaches presented above: flood warnings in

113 the implemented system are based on both (i) distributed rainfall measurements, and (ii) the

114 discharge simulations obtained with a distributed rain-runoff model.

115 This paper describes the GFWS implemented in the Guadalhorce basin and the 116 methodology chosen to workaround the lack of data. Results obtained during two recent 117 flood events that affected the basin have been analysed. Flood warnings issued with the

3 Swiss Federal Research Institute

4 French Hydro-meteorological Nacional Center in charge of Flood Forecasting 
118 GFWS have been compared to effective flooding records collected by the emergency 119 services. In addition, the complementarity between EFAS' low-resolution and long120 anticipation warnings and high-resolution and short-anticipation warnings of the GFWS has

121 been analysed from an operational point of view. The lead-times provided by both systems, 122 and the time separating the warning issuance and the inundation occurrence, have been 123 particularly discussed.

124 The paper is organized as follows. Section 2 presents the framework of study: the 125 Guadalhorce basin and the compilation of historical and real-time hydro-meteorological 126 data. Section 3 describes the distributed hydrological model and the calibration procedure. 127 Section 4 presents the two configurations of the GFWS (based on rainfall and discharge).

128 Two rainfall events that occurred at the beginning of 2010 and caused significant floods are 129 presented in Section 5 as case studies. Section 6 briefly presents EFAS warning system and 130 analyses the warnings delivered for both events. Finally, Section 7 summarizes the main 131 results and concludes on future improvements.

\section{2. Case study:}

\section{2.1. The Guadalhorce basin}

135 The Guadalhorce basin $\left(3200 \mathrm{~km}^{2}\right)$ is located in Andalusia, South of Spain. The river 136 passes through the city of Málaga (500,000 inhabitants) near the outlet of the 137 Mediterranean Sea. The basin is bordered on the West by moderately high mountains (1900 $138 \mathrm{~m}$ amsl) and by a low plateau $(500 \mathrm{~m}$ amsl) on the North. The dominant climate is warm139 temperate Mediterranean, characterized by a marked dry season, with hot summers and 140 generally mild winters. The warmest months are July and August with an average 141 temperature of $23^{\circ} \mathrm{C}$, and the coldest season covers the period between December and 142 February with an average of $13^{\circ} \mathrm{C}$. Annual precipitation is comprised between 500 and 600 $143 \mathrm{~mm}$. Rainfall is concentrated during the period October to April ( $90 \%$ of the total amount). 144 Historically, the Guadalhorce river represents a major risk for the city of Málaga and 145 periodically causes floods along its course. Although the region is mainly rural with 146 dominant bare land cover, stakes are numerous, with the population concentrated close to 
147 Málaga and many activities related to tourism. For this reason, the regional government of

148 Andalusia has decided to implement an operational FWS with the aim of minimizing risk to 149 people and economic activity.

\section{2.2. Hydrometeorological data}

151 The studied watershed is covered by a quite scarce measuring instrumentation network. A 152 total of 25 automatic hourly rain gauges are located within or near the basin (see Fig. 1), 153 representing an average density of about one rain gauge per $180 \mathrm{~km}^{2}$. Such a density can 154 appear insufficient to enable accurate high resolution rainfall estimates through spatial 155 interpolations on small watersheds. Here, time and space scales suited to flash flood 156 dynamics are small: sub-hourly time step and kilometric scale (e.g. Collier 2007; Creutin 157 and Borga 2003; Moulin et al. 2009). Nevertheless, this rain gauge network should be 158 enough for larger basins characterized by a response time at least higher than the rain gauge 159 time step. The region of Málaga is also covered by a C-Band Doppler radar operated by the

160 Meteorological Spanish Agency (AEMET). The radar is located at $1173 \mathrm{~m}$ amsl and fully 161 covers the basin. The GFWS has been developed to operationally consider radar products 162 characterized by a higher spatio-temporal resolution $\left(1 \mathrm{~km}^{2}\right.$ and 10 minutes).

163 Four reservoirs and three hourly automatic gauge stations are also located in the upstream 164 part of the Guadalhorce basin: Bobadilla $\left(761 \mathrm{~km}^{2}\right)$, Ardales $\left(211 \mathrm{~km}^{2}\right)$, and Teba (202

$165 \mathrm{~km}^{2}$ ) as illustrated in Fig. 1. They cover a third of the total basin area, leaving the remaining 166 area ungauged (where Málaga is located). Measured discharges are also available in real 167 time for operational purpose. Available historical discharge data have been compiled since 1682008 to calibrate the rainfall-runoff model.

169 Statistical climate data on historical precipitation are also available (MOPU 1990) as maps 170 of maximum daily rainfall amounts (MOPU 1999), and Intensity-Duration-Frequency 171 curves (IDF), as well as regionalised parameters for the application of the rational Method 172 are described in MOPU (1990). 


\section{Rainfall-runoff model}

174 A grid-based distributed rainfall-runoff model has been implemented and adjusted with the

175 aim of computing warnings based on simulated discharges at every pixel of the grid inside

176 the area of study. Such a distributed structure allows to take into account the spatial

177 variability of precipitation. Due to the lack of historical hydrological data, and in order to

178 simplify the calibration procedure, the model was chosen to be simple, robust, and

179 depending on a reduced number of adjustable parameters.

\subsection{Presentation of the distributed rainfall-runoff model}

181 The Guadalhorce basin has been split into hydrological cells of $1 \mathrm{~km}^{2}$ that are connected to 182 the outlet of the basin following a simplified drainage network based on the analysis of the 183 topography. To take into account the effect of the three dams, it was considered that the 184 drained area located upstream of each dam does not contribute to cells located downstream. 185 Each $1-\mathrm{km}^{2}$ cell is treated as a hydrological unit, where a lumped model is applied. The 186 lumped model employed here is based on the common Soil Conservation Service (SCS) 187 Curve Number $(C N)$ method (Mockus 1957) for computing excess rainfall, combined with 188 the linear diffusive wave unit hydrograph for flow routing (Szymkiewicz 2002).

189 The SCS-CN method assumes that flood flows are essentially composed of surface runoff 190 water or at least fast responding runoff processes. Because of its simplicity and minimal 191 data requirements, the SCS-CN method is widely used in flash flood simulation (see for 192 examples Borga et al. 2007; Rozalis et al. 2010; Versini et al. 2010, 2013). It is based on 193 the water balance equation and a proportionality stating that the ratio of the amount of 194 cumulative infiltration $(F[i]$, in $\mathrm{mm})$ to the amount of potential maximum retention 195 capacity $(S$, in $\mathrm{mm})$ is equal to the ratio of the amount of total runoff volume (V[i], in $\mathrm{mm}$ ) 196 to the maximum potential runoff volume. The latter being represented by the total rainfall 197 amount from the beginning of the event $P_{\text {tot }}[i]$, to which the initial abstraction $I_{a}$ (both in $198 \mathrm{~mm}$ ) is subtracted. Assuming $F[i]=P_{\text {tot }}[i]-I_{a^{-}} V[i]$, the total runoff volume generated at the 199 cell scale is computed as:

$200 V[i]=\frac{\left(P_{t o t}[i]-I_{a}\right)^{2}}{P_{t o t}[i]-I_{a}+S}$ 
201 From this formula, the instantaneous runoff coefficient for time step $i$, $C[i]$, can be 202 deduced. This coefficient has then to be multiplied by the rainfall intensity $P[i]$ to estimate 203 the direct runoff, $Q_{f}[i]$ :

$204 C[i]=\frac{\partial V[i]}{\partial P_{t o t}[i]}=1-\frac{S^{2}}{\left(P_{t o t}[i]-I_{a}+S\right)^{2}}$

205 Retention capacity $S$ is related to the $C N$ coefficient which is usually estimated from the 206 soil properties and taking a value between 0 and 100. The original SCS equation was 207 adjusted for events with large amounts of precipitation accumulated during long periods 208 (several days). Thus, when the total amount of precipitation increases during an event, the 209 soil drainage process is not explicitly represented and there is no possibility for the system 210 to recover the basin's water retention capacity. The instantaneous runoff coefficient 211 increases simultaneously and the simulated direct runoff has a strong tendency to be 212 overestimated. In this study, an attempt was made to take into account the process 213 accumulating rainfall on an adapted time period. After several tests, a period of 24 hours 214 has been arbitrarily chosen to accumulate rainfall:

$215 Q_{f}[i]=P[i] \cdot\left[1-\frac{S^{2}}{\left(P_{24 h}[i]+S\right)^{2}}\right] \quad$ when $P_{t o t}[i]>I_{a}$

$216 Q_{f}[i]=0 \quad$ otherwise

217 Where $\mathrm{P}_{24 \mathrm{~h}}[i]$ is the amount of precipitation in a 24-moving window which ends at time 218 step $i$, and from which the initial abstraction $I a$ is deduced.

219 Additionally, the conceptual function proposed by Weeks and Boughton (1987) has been 220 chosen to model the slow flow $Q_{s}[i]$ :

221

$$
Q_{s}[i]=\Delta t \cdot \alpha \cdot Q_{f}[i]+Q_{s}[i-1] \quad \text { if } \quad Q_{f}[i]>0
$$

222

$Q_{s}[i]=Q_{i n i}+\left[Q_{s}[i-1]-Q_{i n i}\right] \cdot(1-\Delta t \cdot \alpha)$

if $\quad Q_{f}[i]=0$ 
223 Where $\alpha$ (with units of time ${ }^{-1}$ ) is a parameter to calibrate, $\Delta \mathrm{t}$ is the time step, and $Q_{\text {ini }}$ is the

224 initial flow computed with the observed runoff at the beginning of the event.

225 It assumes that there is a constant ratio between the runoff component $Q_{f}[i]$ and the 226 variation of the slow component between two time steps. Base flow is also recursively 227 estimated from the previous value. It is initialized with the initial flow $Q_{i n i}$ measured in 228 gauged cells at the beginning of the event, and extrapolated to the rest of the basin 229 proportionally to the drainage area of each cell. When there is no direct runoff, the 230 recession curve $Q_{s}[i]$ becomes exponential. We have verified that the base flow assumption 231 made does not affect the mass balance, and it is beneficial to improve the representation of 232 the simulated discharge.

233 The total runoff $Q_{t o t}[i]=Q_{f}[i]+Q_{s}[i]$ generated at each cell is then routed downstream 234 following the drainage network. A single unit hydrograph based on the linear diffusive 235 wave function and Muskingum parameters (Szymkiewicz 2002) has been used:

$H U[i]=\frac{1}{\sqrt{2 \pi \cdot(1-2 X)}} \cdot \frac{N}{K} \cdot\left(\frac{K}{i \cdot \Delta t}\right)^{\frac{5}{2}} \cdot \exp \left[-\frac{(i \cdot \Delta t-N \cdot K)^{2}}{2 \cdot(1-2 X) \cdot K \cdot i \cdot \Delta t}\right]$

237 Where $H U[i]$ is the unit hydrograph at time step $i, X$ is the weighting factor (dispersion 238 parameter) that varies between 0 and $0.5, K$ is the storage time for one path, and $N$ the 239 number of paths of the course.

240 A specific unit hydrograph $(H U)$ is defined for both kind of cell. One first $H U$ is applied in 241 each cell to represent the hillslope flow propagation. Then a second is applied on the river 242 course connecting the hillslope cell to the downstream point of interest to represent the 243 propagation of the stream flow. The linear diffusive wave function can represent both 244 processes changing its parameters. For each cell, both hillslope and river routing parameters $245(N, X, K)$ need also to be adjusted. 
248 As described above, the number of parameters to adjust is rather large. It has to be reduced 249 to make the model robust and to limit uncertainty due to over-parameterisation (see Perrin 250 et al., 2001): (i) spatially distributed $C N$ [used in Eq. (3)], the base flow parameter $\alpha$ [see 251 Eq. (4) and (5)] for the loss function and, (ii) spatially distributed routing parameters for 252 both hillslope $\left(N_{h}, X_{h}, K_{h}\right)$ and river $\left(N_{r}, X_{r}, K_{r}\right)$ routing functions.

253 An a priori method has been used to estimate distributed $C N$ values over the entire 254 watershed. Geomorphological data (slope, geology and land cover) at cell scale have been 255 used to compute the $C N$ distribution within the basin with a 1-km resolution according to 256 the recommendations of the Spanish Ministry of Public Works (MOPU 1990). Previous 257 studies based on this method (Corral et al. 2000; 2002) have shown significant differences 258 between effective field capacities and those obtained with this a priori method: simulated 259 discharges have a clear tendency to be overestimated. For this reason, an average curve 260 number correction factor $(F C N)$ has been calibrated to scale the map of $C N$ values. Note 261 that this kind of correction was already used in Borga et al. (2007) for example.

262 In many applications of the SCS method, the initial abstraction $I_{a}$ does not take into account 263 antecedent moisture condition and is deduced from the potential maximum retention $S$. In 264 this study, $I_{a}$ is not considered as a parameter and is assumed to be independent of $S$. It is 265 firstly approximated as the difference between the total amounts of antecedent 266 evapotranspiration and rainfall over the previous 15 days. Then, $I_{a}$ is updated in real time 267 from stream gauge measurements identifying by means of the hydrograph initial rising time 268 (see more details in Corral et al. 2002). $I_{a}$ represents the total amount of precipitation from 269 the beginning of the event to the first initial hydrograph rising time (deducing the response 270 time of the watershed).

271 The three parameters that govern both hillslope and river routing functions have also been 272 simplified. Concerning the hillslope function, $N_{h}$ is fixed to one path, and $X_{h}$ to 0 273 representing a maximum attenuation in peak discharge. Concerning the river function, 274 applied on the river course to the outlet, $N_{r}$ is assumed to represent the number of cells until 275 the outlet; the remaining weighting factor $X_{r}$ needs to be calibrated and is assumed to be 
276 uniform over the basin. Both storage times $K_{h}$ and $K_{r}$ are computed as the ratio between

277 hillslope or river course lengths (derived from the DTM) and flow velocities. These 278 velocities $v_{l}$ and $v_{r}$ are also considered uniform over the basin and represent the last 279 parameters to be calibrated.

280 Summarizing, the adjustment of the model required the calibration of 5 parameters: the 281 curve number correction factor $(F C N)$, the base flow parameter $(\alpha)$, and three routing 282 parameters [hillslope velocity $\left(v_{h}\right)$, river velocity $\left(v_{r}\right)$, river weighting factor $\left(X_{r}\right)$ ].

\section{3.3. Adjustment of the parameters}

285 The rainfall-runoff model described above has been calibrated using observed discharges 286 available at the gauged watersheds (see Section 2). Eight rainfall events for 2008 have been 287 selected for the adjustment of the model parameters. Radar data were not available for this 288 period, so spatially interpolated rain gauge data have been used. The total rainfall amounts 289 of these events were not very large (between 20 and $100 \mathrm{~mm}$ ). The calibration of the model 290 has been carried out with the observations measured at the Bobadilla stream gauge (no 291 significant discharges were measured at the two other stations and/or the data were not 292 available). Because the number of interesting rainfall events was rather small, we chose to 293 calibrate the model manually, and to reproduce the most intense events. The results have 294 been evaluated with the Nash criterion (Nash and Sutcliffe 1970) and are summarized in 295 Table 1.

296 The performance of the model in term of Nash efficiency varies from one rainfall event to 297 another. The simulations accuracy is acceptable in the light of the results obtained in 298 comparable case studies (ungauged basins or poor instrumented framework), for which the 299 model calibration was made with a longer historical database (for example: Borga 2008;

300 Versini et al. 2010). The performance of the model is generally better for the largest rainfall 301 events, where the effort of calibration was made (the more significant events are 302 represented on Fig. 2). The hydrological response to smallest events appears a little more 303 erratic and is probably linked to the non-linearity of the rainfall-runoff transformation. In 304 this case, initial abstraction plays a major role and can strongly affect the simulated 
305 discharges. Note that to achieve reasonable simulations, a curve number correction factor

306 FCN of 0.5 has been chosen, implying that the map of $\mathrm{CN}$ calculated a priori, strongly 307 overestimate discharges. This value may seem rather large, but tends to be common in

308 flood simulation in Mediterranean basins (see Corral et al. 2002; Francés and Benito 1995).

309 Rainfall estimates based on spatial interpolation of rain gauge measurements could also

310 represent a source of uncertainty. The coverage of the current rain gauge network may be

311 insufficient to estimate reliable distributed rainfall in the gauged watershed used for

312 calibration (Bobadilla), where no rain gauge is available inside (see Fig. 1). This may

313 partially explain the differences between simulated and observed discharges.

314 The calibration of the rainfall-runoff model has been carried out under a number of

315 limitations (given the scarcity of data, number of rain gauges, model structure...) that may

316 have a significant impact on the performance of the model. This needs to be considered

317 when analysing the results of the GFWS. Post-flood field investigation and new time series,

318 as they become available, may be used to improve the rainfall-runoff model (specially its

319 calibration).

320 Finally, the values of the parameters calibrated in the Bobadilla stream gauge (i.e. $F C N, \alpha$,

$321 v_{h}, v_{r}$ and $X_{r^{-}}$) have been transferred to the remaining (ungauged) part of the basin,

322 implicitly assuming a similar hydrological behaviour.

\section{4. The GFWS}

324 The purpose of the GFWS, presented here, is to provide distributed warnings based on 325 rainfall accumulations and runoff simulations (at the same resolution of $1 \mathrm{~km}^{2}$ ). In the 326 current configuration, the warnings are computed at each time step from all the 327 precipitation data available up to the present. Three different types of warnings related to 328 hazard probability expressed in terms of return periods are delivered. Two of these are 329 based on rainfall estimates and one on simulated discharges. Note that because of data 330 collection and fast response of small basins, lead times provided by the GFWS are quite 331 short (usually of the order of 1 hour). 


\subsection{Warnings based on rainfall estimates}

333 Without taking into account any hydrological process, the distributed rainfall data can bring 334 a first interesting attempt related to the expected consequences of the rainfall event and to 335 localize the potential inundations. Two different types of warnings can be computed for 336 every cell of the studied area and using these precipitation fields: (i) based on estimated rainfall at point locations (cells of $1 \mathrm{~km}^{2}$ ), (ii) based on spatially aggregated rainfall at each point (i.e. accumulated within the area upstream of each point). These warnings have the advantage to be computed quickly and effectively, without any information other than 340 rainfall.

\section{4.1.1. Use of IDF curves}

342 IDF curves are used as a benchmark for estimating the return period associated with a given 343 rainfall. IDF curves are widely used, and different techniques exist to compute them [see 344 Ben-Zvi, (2009) for an exhaustive review]. In Spain a common methodology is that 345 recommended by the Spanish Ministry of Public Works for drainage design studies (MOPU 346 1990). It has been chosen in this study and has the following synthetic expression:

$347 \quad P_{D}(T)=\frac{P_{24 h}(T)}{24} \cdot F R^{\frac{28^{0.1}-I^{0.1}}{20^{0.1}-1}}$

348 Where $P_{D}(T)$ is the rainfall (in $\mathrm{mm}$ ) associated with a duration $D$ (hours) and a return 349 period $T, P_{24 h}(T)$ is the daily accumulated rainfall $(\mathrm{mm})$ for a return period $T$, and $F R$ is a 350 regional factor equal to 8.5 for the area of study.

351 The extension of IDF to radar rainfall estimates is not straightforward (as illustrated in 352 Norbiato et al. 2007 and Wright et al. 2013). IDF curves are usually developed from rain 353 gauge networks that are often characterized by low spatial density and short observation 354 periods. Moreover, point-to-area transformation is achieved through area reduction factors 355 ignoring local rainfall climatology or storm type (see section 4.1.3). Despite these 356 limitations, the Spanish methodology has been applied here. Finally, IDF maps have been 357 calculated with a resolution of $1 \mathrm{~km} 2$, for different return periods $(2,5,10,25,50,100,200$ 358 and 500 years) and different durations (1, 2, 3, 4, 6, 12 and 24 hours) for both point and 359 spatial aggregated rainfall. 


\subsubsection{Warning based on point rainfall}

361 This type of warning is calculated from the point rainfall measurements accumulated during

362 one hour. It is assumed that this accumulation time is relevant to deliver information about 363 the most critical situations at cell scale. It could be of interest for issuing warning in urban 364 environment or for very sensitive points such as roads (e.g. Versini et al. 2010). The 365 warning computation is based on a direct comparison, cell to cell, between estimated 366 rainfall, and the IDF threshold values computed for $D=1$ hour and different return periods $367 T$. The value assigned to the warning in a particular cell is the maximum of the return 368 period values that has been exceeded by accumulated rainfall estimates.

\section{4.1.3. Warnings based on aggregated rainfall}

370 In this case, the warning is computed to represent as well as possible the consequences of 371 rainfall at watershed scale (every cell draining an area larger than $4 \mathrm{~km}^{2}$ ). With this aim, 372 rainfall is accumulated for a duration $D$ equal to the estimated concentration time of the 373 basin. This concentration time is obtained from both river length and average slope data 374 according to MOPU 1990). These same recommendations propose a correction factor to 375 diminish the thresholds for areal rainfall amount which depends on the drained area $S$ :

$$
k=1-\log \left(\frac{S}{15}\right) \quad \text { when } S>15 \mathrm{~km}^{2}
$$

$377 \quad k=1$

otherwise

\section{4.2. Warnings based on simulated discharges}

380 Warnings based on simulated discharges are computed with the distributed rainfall-runoff 381 model for every cell where the drained area exceeds $10 \mathrm{~km}^{2}$. At these locations, the 382 simulated discharges are compared with peak flow thresholds estimated for return periods $383 T=\{2,5,10,25,50,100,200,500$ years $\}$. They are based on the Rational Method, as 384 described in MOPU (1990). 


\section{Test case studies}

387 The GFWS started operating in May 2009. Little after, two serious rainfall events occurred 388 (in January and February 2010), both resulting in significant flooding in the region of 389 Málaga. These two events were not used in the calibration of the rainfall-runoff model (see 390 Section 3.3), and resulted the largest accumulations since the GFWS has started. As 391 weather radar observations were not available for these events, the rainfall field was 392 estimated by spatial interpolation of rain gauge measurements with a resolution of 1 hour. 393 A third event has been selected. It corresponds to a minor event for which the C-band radar

394 of the Spanish Meteorological Agency (AEMET) located near Málaga was operating. 395 Although no inundation occurred during this event, it illustrates the use of radar QPE. The 396 events and the associated performance of the GFWS are presented herein, also considering 397 the information on the inundations in the Guadalhorce basin reported by the emergency 398 services.

\subsection{Event of 6-7 January 2010}

\section{5.1.1. Description of the rainfall event}

402 The maximum observed accumulations reached up to $70 \mathrm{~mm}$ on the southern portion of the 403 Guadalhorce basin (see Fig. 3-a). The event started at about 23:00 UTC on 6 January 2010 404 and lasted for 12 hours. However, most of the precipitation was registered between 08:00 405 and 10:00 UTC (during this period rain gauges around Málaga registered accumulations of $40640 \mathrm{~mm}$ ) as a consequence of a mesoscale convective system sweeping the basin.

407 The intense precipitation registered in the morning of 7 January caused flooding of houses, 408 basements, garages and streets, mainly in the suburbs of Málaga and in Alhaurín de la 409 Torre (Fig. 4): emergency services registered a hundred flooding incidences between 9:00 410 and 10:00 UTC in these two cities. These areas are frequently affected by inundations and 411 this event illustrates a typical case of urban flash flood due to an intense storm that is not 412 rare in southern Andalusia. 
413 During this event, two of the three stream gauges of the basin (Bobadilla, Teba) operated 414 normally. These gauges (see Fig. 1) are located far upstream from the area mostly affected 415 by precipitation (around the city of Málaga), and the total precipitation amounts in the sub416 catchments drained at these points were relatively minor (around $30 \mathrm{~mm}$ ). Consequently, 417 the resulting observed discharges were not significant (see Table 2).

\section{$418 \quad$ 5.1.2. Performance of the GFWS}

419 The comparison between stream gauge observations and the simulations obtained with the

420 rainfall-runoff model at these locations show some agreement, as quantified in terms of the 421 Nash efficiency (presented in Table 2). It is worth noting the performance of the model at 422 the stream gauge in Teba, whose measurements were not used in the calibration of the 423 rainfall-runoff model (stated in Section 3.3).

424 The GFWS was able to issue warnings in the areas where flooding actually occurred. Fig. 4 425 shows the maximum warnings based on point rainfall (issued at 9:00 UTC), and based on 426 aggregated rainfall and simulated discharges (both at 10:00 UTC). Concerning the former 427 (Fig. 4a), a warning was issued around the city of Málaga and matching the area where the 428 most intense convective cell affected the basin. The core of the warning (in green) 429 corresponded to an hourly intensity over $35 \mathrm{~mm} / \mathrm{h}$, which correspond to a return period of 430 around 5 years. Around this core, the 2-year return period warning level was reached in the 431 blue area (which corresponds to an average hourly intensity over $25 \mathrm{~mm} / \mathrm{h}$ ). These patterns 432 had some correspondence with the flooding that occurred in this area between 9:00 and 433 10:00 UTC. These warnings were confirmed by those based on aggregated rainfall and 434 simulated discharge in the area. Because these two use information on the spatial structure 435 of the basin, they have advantage to localize more precisely the location of potential 436 flooding. Both predicted the maximum threat of flooding at 10:00 UTC West of Málaga 437 (Fig. 4-b and 4-c), where a small tributary stream crosses the suburbial industrial area, and 438 at Alhaurín de la Torre (respectively, draining basins of 30 and $73 \mathrm{~km}^{2}$ ). Both criteria were 439 consistent with each other and only differed on the assigned return periods: 2 years when 440 assessed based on aggregated rainfall and 5 years when the computations are based on 441 simulated discharges. This difference is due to the estimated initial abstractions almost 
442 equal to 0 . In any case, these warnings coincided very well with the reaches where flooding

443 was reported within the basin.

\section{5.2. Event of 15-16 February 2010}

\section{5.2.1. Description of the rainfall event}

447 There are clear differences between this rainfall event and that presented in Section 5.1:

448 Rainfall intensities were much lighter, maximum hourly intensities hardly exceeded 20

$449 \mathrm{~mm} / \mathrm{h}$, but it lasted significantly longer (it did not stop raining for about 24 hours), which

450 resulted in progressive saturation of the soils of the basin. The area located near the coast

451 was particularly affected, with substantial amounts of rainfall registered in Alhaurín de la

452 Torre (totals reached up to $215 \mathrm{~mm}$-nearly a third of the mean annual precipitation), and

453 over $100 \mathrm{~mm}$ around Málaga (see Fig. 3-b). In terms of daily rainfall, and according to

454 MOPU (1990), the 50 years return period $(180 \mathrm{~mm})$ was exceeded in Alhaurín de la Torre,

455 and it was between 5 and 10 years (90 and $115 \mathrm{~mm}$, respectively) in Málaga. Along the

456 event, the accumulated precipitation caused several floodings in the morning of 16

457 February 2010 (after 24 hours of precipitation). The rescue services did more than 40

458 actions related to flooding (essentially homes and garages) in several municipalities in the

459 province of Málaga: Alhaurín de la Torre, Coín, Campanillas and Cártama (see Fig. 5).

460 These actions included the use of helicopters to evacuate people trapped at home or in 461 flooded roads.

462 As in the previous event, the largest rainfall amounts occurred downstream the gauged 463 watersheds (50 and $20 \mathrm{~mm}$ in the sub-basins of Ardales and Bobadilla, respectively). As a 464 result, observed discharges were not significantly high, and the observed peaks were 465 comparable to those of 6-7 January 2010 (see Table 2).

\subsubsection{Performance of the GFWS}

467 The hydrographs simulated with the rainfall-runoff model can be considered acceptable in 468 terms of the Nash efficiency (see Table 2). Despite of the rough calibration, the model 469 seems to reproduce correctly the hydrological response at the location of stream gauges. 
470 The GFWS was able to issue consistent warnings in the flooded areas depending on the 471 type of warning used (based on rainfall or simulated discharge). As explained above, the 472 large rainfall accumulations recorded during this event were the result of the long duration 473 of the event, rather than very intense precipitation. As a result, observed precipitation 474 intensities did not exceed the thresholds to issue warnings based on hourly point rainfall at 475 any time: The highest observed intensity in the basin was around $20 \mathrm{~mm} / \mathrm{h}$, lighter than the 476 average value for the 2 -year return period around $25 \mathrm{~mm} / \mathrm{h}$.

477 The highest warning levels issued based on aggregated rainfall and simulated discharges 478 are presented in Fig. 5 (at 6:00 and 7:00 UTC, respectively). Aggregated rainfall exceeded 479 the 2-year return period for the first time at 03:00 UTC in the main stream between Coín to 480 Málaga. The levels progressively increased and at 6:00 UTC the 5-year return period was 481 exceeded. At the same time, small tributaries to this main stream were also marked as 482 potentially flooded. It is clear how the areas where the warnings were issued match the 483 points where the main floods actually occurred (Alhaurín de la Torre, Coín, Cártama, and 484 Málaga, circled with solid red ellipses), being the only exceptions Campanillas and the 485 suburbs of Málaga where no warning was issued. After 3:00 UTC, warning levels 486 decreased and remained only for the main stream. At 12:00, 4 hours after the rainfall had 487 ceased, only the Guadalhorce stream located between Cártama and Málaga was identified 488 as a risky area and remained so until the end of the day.

489 Warnings computed from simulated discharges were more intense and more numerous than 490 those already calculated with the aggregated rainfall (the estimated initial abstractions were 491 null). Indeed, the first warning appeared at 23:00 UTC, and at 3:00 UTC exceeded the 492 return period of 5 years (i.e. higher than the 2-year one issued for aggregated rainfall). At 493 7:00 UTC, the simulated discharges passing through Cártama and Alhaurín de la Torre 494 were exceeding the 25-year return period, and in Coín, Campanillas and Málaga, the 10495 year return period. The simulated peak discharge in Málaga outlet occurred at 10:00 and 496 reached a value of $817 \mathrm{~m}^{3} / \mathrm{s}$, although rescue services, based on ground observation, 497 estimated the discharge to temporarily exceeded $2000 \mathrm{~m}^{3} / \mathrm{s}$. The fact that drained area 498 located upstream of each dam were not considered can explain this large difference. 499 Warnings based on simulated flows, thus, corresponded very well with the floods that 
500 occurred in this area. Unlike for the warnings based on aggregated rainfall, the flooding in

501 Campanillas and the suburbs of Málaga at 7:00 UTC (see Fig. 5-b) were not missed:

502 warnings of 10- and 5-year return period were issued at these points, respectively.

503 A flood warning (5-year return period) was also issued for the Ardales stream, downstream

504 of one of the dams of the basin (Conde Guadalhorce dam, surrounded in Fig. 5-b), where

505 no problem actually occurred. This area is not anthropized and for this reason was not

506 affected. As the simulated discharge was not propagated downstream the dam, no warning 507 was issued further.

\section{5.3. Event of 21 April 2011}

\section{5.3.1. Rainfall inputs: processing of radar data}

510 The very-high resolution of radar QPE products both in space and time (for the case of the

511 Málaga radar, $1 \mathrm{~km}$ and 10 minutes) fits very well the requirements of flood monitoring in

512 fast response basins such as the Guadalhorce basin, as it allows an accurate representation

513 of the variability of the rainfall field and capture local intensities that could be missed by

514 rain gauge networks. However, radar measurements require a thorough processing to

515 convert them into Quantitative Precipitation Estimates.

516 In our case, we have implemented the chain of algorithms of the EHIMI package (Corral et

517 al. 2009), which includes: (i) reduction of the effects of beam blockage by the orography

518 using the approach of Delrieu et al. (1995), (ii) clutter elimination with the technique of

519 Sánchez-Diezma et al. (2001), (iii) identification of the type of precipitation and

520 extrapolation of elevated reflectivity measurements to the surface according to a double

521 Vertical Profile of Reflectivity as described by Franco et al. (2006, 2008), and (iv)

522 conversion of reflectivity into rain rate using a double Z-R relationship for stratiform and

523 convective rain. Hourly accumulations were generated from instantaneous rainfall maps

524 with an algorithm similar to that of Fabry et al. (1995). 


\section{5.3.2. Description of the rainfall event}

526 The river rise of 21 April 2011 is the result of a widespread system that crossed Andalusia

527 from west to east. Over the basin, $10 \mathrm{~mm}$ of rainfall were accumulated in 10 hours

528 (approximately from 14:00 UTC to 24:00 UTC), with totals locally reaching up to $25 \mathrm{~mm}$

529 near Málaga and on the southern portion of the Guadalhorce basin (see Figure 6-a). The

530 most intense precipitation was concentrated at about 17:00 UTC with local hourly

531 intensities around $20 \mathrm{~mm} / \mathrm{h}$.

532 The event accumulation based on radar measurements does not show the artefacts that

533 frequently affect radar rainfall products (due to e.g. sub-estimation "corridors" due to beam

534 blockage or systematic holes from ground clutter filters). It is also noticeable that radar-

535 based QPE values at gauge locations reasonably matches rain gauge records inside the

536 basin (the differences can be attributed to remaining errors in radar QPE, errors in rain

537 gauge measurements and representativeness errors, since the two systems measure rainfall

538 at different scales).

\section{5.3.3. Performance of the GFWS}

540 During 21 April 2011, the GFWS did not deliver any warnings whatever the type (based on

541 point rainfall, spatially aggregated rainfall or simulated flows). Despite some intense

542 precipitation, no significant increase in discharge was noticed and no alert thresholds were

543 exceeded. The propagation of rainfall through the drainage network reduced the magnitude

544 of the hazard, which was already low in terms of point rainfall.

545 However, the benefit of using radar-based QPE is illustrated by the location of intense

546 precipitation (about $20 \mathrm{~mm} / \mathrm{h}$ ) around Málaga and in the central part of the basin at 17:00

547 UTC. As shown in Figure 6, there is no rain gauge at the location where the most intense

548 precipitation occurred, and the field interpolated from rain gauges did not reproduce these

549 local rainfall intensities (or any warning, see Fig. 6-c). Despite some possible

550 overestimation of the radar-based QPE, this proves the use of weather radar may provide a

551 better understanding of intense rainfall away from the rain gauge network. These

552 differences could have been even more significant for more convective situations

553 characterized by very intense local rainfall. 
554 It has to be noticed that no flooding occurred during this event. This is also a satisfactory

555 result for the GFWS, which can be interpreted as follows: First, spatial distribution of 556 precipitation represented by radar-based QPE indicate the location and timing of the highest

557 intensities, which can identify the possible consequences caused by direct rainfall as it may

558 be the case of local floodings in urban areas. Second, the absence of warning in the river 559 network shows there was no significant consequence in terms of discharges, showing that,

560 for this particular case, the rainfall-runoff model did not overestimate the discharges 561 produced by moderate rainfall.

\section{5.4. General comments}

563 Regarding the two examples for which flooding occurred, warnings based on point rainfall 564 seem to be well adapted to prevent from the consequences on the ground of intense 565 precipitation. They are particularly useful to alert of urban flood where the rainfall is 566 directly responsible for flooding. As the current GFWS does not take into account urban 567 drainage (which requires a cadastral resolution), theses warnings could be sufficient to 568 localize the areas prone to flooding during intense precipitation event.

569 Although the model was calibrated for only one gauged basin and for few rainfall events, 570 the results computed with the rainfall-runoff model for these two recent events are rather 571 satisfactory: the simulated discharges calculated at the other stream gauges locations are 572 quite similar to the observed ones. The fact that only warnings based on simulated

573 discharge have pointed out every effective flooding for both events, illustrates the interest 574 of working with a distributed rainfall-runoff model. This rather positive result could, at 575 least in part, be attributed to the significant magnitude of the events, especially given the 576 limitations of the model calibration.

577 Moreover, return period characterizing warnings based on simulated discharges appear to 578 be higher than those based on aggregated rainfall for both studied rainfall events. Regarding 579 the consequences at the ground and the frequency of the total amount of precipitation 580 locally measured, discharge return periods seem to be the more representative. In these 581 cases, the underestimation of aggregated rainfall-based warning may be due to different 582 reasons. First, this method has intrinsic limitations due to the non-consideration of rainfall- 
583 runoff transformation. Second, the antecedent soil moisture conditions, which have a 584 significant role in the catchment response (see e.g. Merz and Blöschl 2009), is not 585 considered. Despite the basic function used to estimate initial losses, the rainfall-runoff 586 model is able to take into account soil moisture via the parameter $I_{a}$ in Eq. 3. For both 587 studied events, the estimated initial abstractions were almost equal to 0 , which result to 588 increase the amount of water producing runoff.

589 These provisional remarks have to be taken with caution because based on the analysis of 590 only two events. They have to be confirmed in the future by studying the performances of 591 the GFWS for new rainfall events.

\section{6. Combined use of EFAS with the GFWS for flood forecasting}

\section{6.1. The European Flood Alert System (EFAS)}

595 The European Flood Alert System (Thielen et al. 2009) issues flood warnings based on 596 probabilistic flood forecasts with lead times up to 10 days at European scale. It is based on 597 the hydrological model LISFLOOD (Van Der Knijff et al. 2010) and rainfall inputs come 598 from a medium-range ensemble weather predictions (NWP-EPS), consisting of a first set of 59951 members generated at the European Centre for Medium-range Weather Forecasts 600 (ECMWF) over a 80-km grid, and a second set of 16-member ensemble from the COSMO 601 Consortium (COSMO-LEPS), run at 10-km grid resolution. Both sets of weather forecasts 602 are included in the hydrological model to produce two ensembles of 51 and 16 members of 603 flow forecasts. The hydrographs generated in such a way are then analysed to issue early 604 warnings on the basis of a threshold exceedance analysis.

605 LISFLOOD was not adjusted for the Guadalhorce basin using discharge measurements (as 606 it is for other European catchments). However, the discharge thresholds associated to flood 607 warnings are directly defined based on a statistical analysis of simulated discharges over a 608 historical 30-year period. The highest discharge obtained from these long-term simulations 609 is used to set the "severe" situation (that is, when the model outputs exceed the 30-year 610 maximum flow situation, a "severe" warning is issued). Similarly, the discharge value 
611 corresponding to the $99 \%$ percentile of historical flow simulations is chosen as the 612 threshold for which a "high" warning is issued. When comparing "high" discharges with 613 records from level gauges in Europe where the model was calibrated, Thielen et al. (2009) 614 reported that the value obtained for "high" warnings usually corresponds to return periods 615 around 1 to 2 years.

\section{6.2. EFAS forecasts for the studied events}

617 EFAS did not issue any warning in advance for the case of 6-7 January 2010 (neither for 21

618 April 2011), since rainfall accumulations were due to a local and intense rainfall core that 619 NWP-EPS had missed.

620 Alternatively, for the second event (15-16 February 2010) the NWP-EPS did depict the 621 main space and time features of the rainfall field. Consequently, EFAS delivered flood 622 warnings with an anticipation of four days: probabilistic forecasts issued a significant flood 623 warning on the main stream of the Guadalhorce River between the 3 dams and Málaga, 624 leaving the secondary streams (where most of the inundations occurred) safe. From the 51 625 ECMWF members, 80\% forecasted floods, whereas the simulations of 2 of the 16 COSMO 626 members exceed the threshold of "high" level 4 days in advance (8 out of 16 members 2 627 days in advance). For this second event, the outlet peak flow simulated with LISFLOOD 628 was around $160 \mathrm{~m}^{3} / \mathrm{s}$. Although this is enough to exceed the "high" level warning in the 629 Guadalhorce basin (around $142 \mathrm{~m}^{3} / \mathrm{s}$, and, as discussed above, corresponding to a 1-2 years 630 return period), it is far from the maximum discharges simulated with the GFWS $\left(817 \mathrm{~m}^{3} / \mathrm{s}\right.$ 631 in Málaga) and the 25-year return period obtained for the GFWS simulations (see section 632 5.2). We believe that the latter may be more accurate as it matches better the reports of 633 local rescue services, which had not faced similar flooding for 20 years (reports based on 634 eye witness estimated the peak flows in about $2000 \mathrm{~m}^{3} / \mathrm{s}$, higher than the 100 -year return 635 period). It is worth insisting on that the version of EFAS currently running in the 636 Guadalhorce basin is uncalibrated, and, therefore, flow simulations cannot be interpreted in 637 absolute terms. Also, it is necessary to remark that no intermediate threshold is established 638 between the "high" and "severe" warnings, which in cases such as the one analysed here 639 could have helped. Note that a more general discussion on the matching between simulated 640 discharges and reference thresholds is conducted in the last section. 


\subsection{Use of EFAS warnings to extend lead-time}

642 In the case studies, most of the watersheds responsible for flooding are small (less than 100

$643 \mathrm{~km}^{2}$ ) and, consequently, characterized by short response times (less than 1 hours). In the

644 operational framework, GFWS warnings based on weather radar and/or rain gauges

645 measurements require the collection of rainfall measurements (which, currently, takes up to

64620 minutes). This means that it takes very short time after the warnings are issued for the

647 inundations to occur in the smallest watersheds (or even equal to 0). This is often

648 insufficient to prevent the concerned population from the flooding. Recent works (e.g.

649 Creutin et al. 2009; Siccardi et al. 2005) have shown that when the social response time is

650 longer than the catchment response time, the planning of management measures requires

651 the use of forecast rainfall fields such as NWP-EPSs. That is why mid-term rainfall

652 forecasts and EFAS warnings represent a good complementary tool for the GFWS.

653 Delivering these forecasts some days in advance, despite the rough spatial accuracy, can be

654 useful from a practical point of view. They can be used as pre-alarms to inform decision-

655 makers about a possible flooding and advise the population, for example, to reduce their

656 trips and to protect vulnerable items. Similarly, emergency services can prepare their teams

657 and anticipate their future actions around the areas of possible flooding to intervene more

658 rapidly the day in question. According to this configuration, the warnings issued by EFAS

659 on the main stream of the Guadalhorce for the 15 and 16 February 2010 could help to limit

660 damages. Warnings issued by the GFWS could have then been used to act more precisely

661 on the affected tributaries.

\section{7. Discussion and Conclusion}

663 A local Flood Warning System has been implemented in the Guadalhorce basin, frequently

664 affected by plain floods and flash floods. The system delivers distributed warnings over the

665 entire basin based on the available sources of information: rainfall estimates and runoff

666 simulations are compared to pre-computed values of hazard probability (separately for

667 rainfall and runoff) to determine the warning level expressed in terms of return period.

668 The performance of the GFWS has been demonstrated on two major events that occurred in

669 the basin at the beginning of 2010 (the most intense since the system is operating). In 670 general, the warnings issued by the system matched the timing and location where actual 
671 inundations occurred. The performance of the system during the presented cases has shown 672 how the different warnings (based on rainfall estimates or on flow simulations) are well 673 adapted to the types of hazard that affect the Guadalhorce basin. Indeed, results obtained 674 for 7 January 2010 confirm that warnings based on point rainfall are well adapted to alert of 675 urban or flash floods, as they are driven by very intense precipitation. As urban drainage is 676 not considered in the system, the precise location of intense rainfall could be enough from 677 the end-user point of view. On the other hand, results obtained on 16 February 2010 678 illustrate the effectiveness of warnings based on aggregated rainfall and discharge 679 simulations to forecast the inundations caused by stream overflows.

680 Moreover, on the analysed events, a significant difference has also been noticed between 681 the return period characterizing warnings based on aggregated rainfall and simulated 682 discharges. Those calculated with the rainfall-runoff model, usually higher, have also 683 pointed out every effective flooding. This underlines the importance of taking into account 684 rainfall-runoff transformation and antecedent soil moisture conditions.

685 In parallel, the European Flood Alert System (EFAS) has proved to be a valuable 686 complementary tool for flood warning. It forecasted the consequences of the larger-scale 687 and long-lasting event of 15-16 February 2010 four days in advance. Although it did not 688 forecast the exact location of flooding and underestimated the magnitude of the event, it 689 provided useful information to prepare the emergency services to operate. However, EFAS 690 did not anticipate the event of 7 January 2010, for which GFWS showed a good 691 performance. We attribute this miss mainly to the inability of the NWP-EPS model to 692 depict the intense but very local precipitation system that produced the event. This kind of 693 events show the interest of rapid-updating and high-resolution FWSs to issue warnings at 694 resolutions that are closer to the scales at which flooding occurs in this basin (for the 695 analysed events most of the inundations occurred in secondary streams for which EFAS 696 does not produce flow forecasts).

697 The presented results illustrate the interest of using the GFWS for flood warning in the 698 Guadalhorce basin, but it has to be recalled that this analysis is based on the study of only 699 two rainfall events. These conclusions need to be confirmed in the future regarding the 
700 performance of the GFWS on new events. In addition, there are a number of implicit

701 hypotheses and limitations that are worth discussing:

702 (1) The selection of thresholds for issuing warnings with GWFS is arbitrary according to 703 the usual practices in Spain (i.e. according to the MOPU 1990 and 1999 for runoff and 704 rainfall respectively). This is so because long series of observations are inexistent in the 705 basin. In particular, the method used for setting flow warning thresholds uses historical 706 daily rainfall accumulations (implicitly assuming a very simple rainfall-runoff model to 707 estimate design peak flows). This results in some sort of inconsistency when the discharges 708 simulated with the rainfall-runoff model presented in section 3 are compared to the 709 thresholds established with an obviously different model. The availability of longer series 710 of hydrological records would allow establishing better thresholds (e.g. as suggested by 711 IACOW 1982 and Reed et al.2007). In any case, the used thresholds can still be considered 712 as indicators of the relative degree of severity of the events, despite the fact that the 713 associated return periods cannot be taken in absolute sense. For example the results 714 presented above show a clear correspondence between the issued warnings and the reported 715 inundations, and indicate relative significance of the events, but cannot be considered 716 extreme (the 100-years return period was certainly not exceeded).

717 (2) The number of hydrometeorological sensors (both rain and stream gauges) in the basin 718 poses an important challenge for the performance of the GFWS. The density of rain gauges 719 (in average, 1 every $180 \mathrm{~km}^{2}$ ) and its time resolution (1 hour) limit the ability of the system 720 to monitor the variability of the rainfall field at smaller scales, thus reducing the skill of the 721 system to forecast flooding due to very local precipitation, especially in convective 722 situations. However, this factor did not seem to be critical for the case of January 2010 723 presented above: although intense rainfall was mainly localized in the southern part of the 724 catchment and gauges recorded maximum accumulations of $40 \mathrm{~mm}$ in 2 hours (see section 725 5.1), the system was able to diagnose the magnitude of the event and useful warnings were 726 issued. On the other hand, the number of stream gauges and their location (around $40 \mathrm{~km}$ 727 from the outlet of the basin) implies that the calibration of the rainfall-runoff model is 728 mostly valid for the upper part of the basin. Consequently, the simulations obtained 729 downstream (for instance in the area near Málaga, more urbanized than the upper part) are 
730 based on an extrapolation of the calibrated parameters, which are assumed to be valid for

731 the entire basin. The lack of flow measurements downstream does not allow any 732 quantitative validation of the simulations.

733 (3) As it has been implemented here, the GFWS has been run with rainfall observations, 734 and, consequently, the results presented above assess the ability of the GFWS to emulate 735 the response of the catchment for two case studies. However, from the operational point of 736 view, it is also fundamental to analyse the ability of the system to forecast the hydrological 737 response of the basin (and resulting warnings) upon all the knowledge available up to the 738 present (see Todini 1988). By only using rainfall observations, the flow forecasting skill is 739 limited to the response time of the considered basin (Berenguer et al. 2005; Vivoni et al. 740 2006). On top of that, the time resolution of rainfall records (1 hour for rain gauge records) 741 and the data collection time (about 20 minutes) are factors that reduce the time between the 742 forecasts/warnings are issued and the inundations occur. That means the current 743 configuration of the GFWS (using only rain gauge data) may provide valuable flood 744 warnings only for basins larger than $200 \mathrm{~km}^{2}$, with response times over 1 hour. In other 745 words, the system evaluates what is happening in the smallest basins and has some 746 predictive skill for the largest ones thanks to the response time of the basin.

747 In part, (2) can be addressed with the use of radar-based QPE maps (as illustrated for a 748 minor event in Section 5.3): these allow monitoring the space and time variability of the 749 rainfall field at resolutions fulfilling the requirements of rainfall-runoff model for small- to 750 medium-sized basins (see, among many others, Sempere-Torres et al. 1999; Rossa et al. 751 2005; Cole and Moore 2008; Corral et al. 2009; Delrieu et al. 2009). However, it has been 752 classically recognized that there are a number of errors (listed, e.g. by Zawadzki 1984; 753 Austin 1987; Joss and Waldvogel 1990) that affect radar-based QPE and that require the 754 implementation of sophisticated algorithms to mitigate their effect (also, the blending of 755 radar QPE maps with rain gauge measurements has shown significant improvements -see, 756 e.g. Velasco-Forero et al. 2009 ; Schiemann et al. 2010 and references therein-).

757 Radar rainfall products also allow generating very short-term rainfall forecasts (nowcasts) 758 that can be used to extend the time series of rainfall inputs to the rainfall-runoff model 759 [critical in point (3) above]. Previous works on this subject show significant improvements 
760 in the quality of forecasted hydrographs (see Berenguer et al.2005; Versini 2012; Vivoni et 761 al. 2006; Zappa et al. 2011): The anticipation of flow peaks could be extended for up to a 762 few hours in small to medium basins and, when included in the GFWS, should enable 763 improving the skill of the system for flood forecasting. Beyond these time horizons (critical

764 for flood management and rescue services to prepare and plan their actions), rainfall 765 forecasts based on the combination of radar-based products with numerical weather 766 prediction (NWP) precipitation outputs (as suggested by Li and Lai 2004; Lin et al. 2005; 767 Atencia et al. 2010) should be used. Also, other works (see Jasper et al. 2002; Zappa et al. 7682010 and references therein) have shown the interest of coupling NWP precipitation 769 outputs for flood forecasting in small and medium catchments. In our case, it represents an 770 opportunity to fulfil the gap between the lead-times provided by EFAS (several days in 771 advance) and those provided by the GFWS (few hours in the best case). The 2 or 3 hours 772 gained by this combination are critical in crisis management. They should be useful to 773 anticipate the direct consequences of the current event and to optimize emergency services 774 resources. It should also allow to better anticipate small-scale event and to deliver warning 775 on smaller watersheds.

776 In this sense, it should be noted that the GFWS is ready to use any gridded rainfall product.

777 In particular, the GFWS is currently using the radar-based QPE and QPF products 778 generated with the EHIMI packages using observations from the Málaga radar (not 779 available for the analysed events). As discussed above, with the inclusion of these high780 resolution precipitation products we expect a better performance of the system, especially 781 for issuing warnings at local scales.

\section{Acknowledgments}

783 The authors would like to thank Red HIDROSUR (Southern Andalusia Hydrological 784 Network) and the AEMET (Spanish Meteorological Agency) for providing historical 785 hydrometeorological data on the Guadalhorce basin. We would also like to thank the Joint 786 Research Centre (JRC) for providing preliminary EFAS outputs for the studied cases. This 787 work has been carried out within the European 7th FP project IMPRINTS 788 (http://www.imprints-fp7.eu) and the Spanish projects FFGRad (CGL2009-13139) and 789 ProFEWS (CGL2010-15892), and has been supported by the environmental management 
790 company EGMASA (currently, Agencia de Medio Ambiente y Agua de Andalucía, 791 Consejería de Medio Ambiente - Junta de Andalucía). The second author is supported by a 792 Ramón y Cajal grant of the Spanish Ministry of Science and Innovation (RYC2010-06521). 


\section{References}

795 Alfieri, L., Velasco, D. and Thielen, J. (2011) Flash flood detection through a multi-stage 796 probabilistic warning system for heavy precipitation events. Advances in Geosciences, 29: $797 \quad 69-75$.

798 Atencia, A., Rigo, T., Sairouni, A., Moré, J., Bech, J., Vilaclara, E., Cunillera, J., Llasat, 799 M.C. and Garrote, L. (2010) Improving QPF by blending techniques at the Meteorological 800 Service of Catalonia. Natural Hazards and Earth System Sciences, 10(7): 1443-1455.

801 Austin, P.M. (1987) Relation between measured radar reflectivity and surface rainfall. 802 Monthly Weather Review, 115: 1053-1070.

803 Barredo, J. I. (2007) Major flood disasters in Europe: 1950-2005. Natural Hazards, 42: $804 \quad 125-148$.

805 Ben-Zvi, A. (2009) Rainfall intensity-duration-frequency relationships derived from large 806 partial duration series. Journal of Hydrology, 367(1-2): 104-114.

807 Berenguer, M., Corral, C., Sánchez-Diezma, R. and Sempere-Torres, D. (2005) 808 Hydrological Validation of a Radar-Based Nowcasting Technique. Journal of 809 Hydrometeorology, 6(4): 532-549.

810 Berne, A., ten Heggeler, M., Uijlenhoet, R., Delobbe, L., Dierickx, P. and de Wit, M.

811 (2005) A preliminary investigation of radar rainfall estimation in the Ardennes region and a 812 first hydrological application for the Ourthe catchment. Natural Hazards and Earth System 813 Sciences, 5: 267-274.

814 Blöschl, G. and Sivapalan, M. (1995) Scale issues in hydrological modelling: A review. 815 Hydrological Processes, 9(3-4): 251-290.

816 Borga, M. (2008) Realtime guidance for flash flood risk management.

817 Borga, M., Boscolo, P., Zanon, F. and Sangati, M. (2007) Hydrometeorological analysis of 818 the August 29, 2003 flash flood in the eastern Italian Alps. Journal of Hydrometeorology, 819 8(5): 1049-1067. 
820 Borga, M., Degli Esposti, S. and Norbiato, D. (2006) Influence of errors in radar rainfall

821 estimates on hydrological modeling prediction uncertainty. Water Resources Research, 822 42(8): 1-14.

823 Carpenter, T.M. and Georgakakos, K.P. (2006) Intercomparison of lumped versus 824 distributed hydrologic model ensemble simulations on operational forecast scales. Journal 825 of Hydrology, 329(1-2): 174-185.

826 Cole, S.J. and Moore, R.J. (2008) Hydrological modelling using raingauge-and radar-based 827 estimators of areal rainfall. Journal of hydrology 358(3-4): 159-181.

828 Collier, C.G. (2007) Flash flood forecasting: what are the limits of predictability ? 829 Quarterly Journal of the Royal Meteorological Society, 133: 3-23.

830 Corral, C., Berenguer, M., Sempere-Torres, D. and Escaler, I. (2002) Evaluation of a 831 conceptual distributed rainfall-runoff model in the Besòs catchment in Catalunya using 832 radar information, Second European Conference on Radar Meteorology. European 833 Meteorological Society, Delft, Netherlands, pp. 409-415.

834 Corral, C., Sempere-Torres, D., Revilla, M. and Berenguer, M. (2000) A semi-distributed 835 hydrological model using rainfall estimates by radar. Application to Mediterranean basins. 836 Physics and Chemistry of the Earth, Part B: Hydrology, Oceans and Atmosphere, 25(10837 12): 1133-1136.

838 Corral, C., Velasco, D., Forcadell, D., Sempere-Torres, D. and Velasco, E. (2009) 839 Advances in radar-based flood warning systems. The EHIMI system and the experience in 840 the Besos flash-flood pilot basin. In: P. Samuels, S. Huntington, W. Allsop and J. Harrop 841 (Editors), Flood Risk Management: Research and Practice. Taylor \& Francis Group, 842 London.

843 Costa, J.E. and Jarett, R.D. (2008) An evaluation of selected extraordinary floods in the 844 United States reported by the US, Geological Survey and implications for future 845 advancement of flood science, Reston, Virginia. 
846 Creutin, J.-D. and Borga, M. (2003) Radar hydrology modifies the monitoring of flash

847 flood hazard. Hydrological Processes, 17(7): 1453-1456.

848 Creutin, J.D., Borga, M., Lutoff, C., Scolobig, A., Ruin, I. and Créton-Cazanave, L. (2009)

849 Catchment dynamics and social response during flash floods: the potential of radar rainfall

850 monitoring for warning procedures. Meteorological Applications, 16(1): 115-125.

851 Delrieu, G., Braud, I., Berne, A., Borga, M., Boudevillain, B., Fabry, F., Freer, J., Gaume, 852 E., Nakakita, E., Seed, A., Tabary, P. and Uijlenhoet, R. (2009) Weather radar and 853 hydrology. Advances in Water Resources, 32(7): 969-974.

854 Delrieu, G., Creutin, J.D. and Andrieu, H. (1995) Simulation of Radar Mountain Returns 855 Using a Digitized Terrain Model. Journal of Atmospheric and Oceanic Technology, 12(5): 856 1038-1049.

857 Fabry, F. and Zawadzki, I. (1995) Long-Term Radar Observations of the Melting Layer of 858 Precipitation and Their Interpretation. Journal of the Atmospheric Sciences, 52(7): 838859851.

860 Francés, F. and Benito, J. (1995) La modelización ditribuida con pocos parametros de las 861 crecidas. Ingenieria del Agua, 2(4): 7-24.

862 Franco, M. (2008) Estimación cuantitativa de la lluvia mediante radar meteorológico. 863 Corrección del error asociado a la variación vertical de la reflectividad, Universitat 864 Politècnica de Catalunya, Barcelona, Spain, 251 pp.

865 Franco, M., Sanchez-Diezma, R. and Sempere-Torres, D. (2006) Improvements in weather 866 radar rain rate estimates using a method for identifying the vertical profile of reflectivity 867 from volume radar scans. Meteorologische Zeitschrift, 15(5): 521-536.

868 Gaume, E., Bain, V., Bernardara, P., Newinger, O., Barbuc, M., Bateman, A., 869 Blaskovicov•, L., Blöschl, G., Borga, M., Dumitrescu, A., Daliakopoulos, I., Garcia, J., 870 Irimescu, A., Kohnova, S., Koutroulis, A., Marchi, L., Matreata, S., Medina, V., Preciso, 871 E., Sempere-Torres, D., Stancalie, G., Szolgay, J., Tsanis, I., Velasco, D. and Viglione, A. 
872 (2009) A compilation of data on European flash floods. Journal of Hydrology, 367(1-2): $873 \quad 70-78$.

874 Georgakakos, K.P. (2006) Analytical results for operational flash flood guidance. Journal 875 of Hydrology, 317(1-2): 81-103.

876 Germann, U., Berenguer, M., Sempere-Torres, D. and Zappa, M. (2009) REAL - Ensemble 877 radar precipitation estimation for hydrology in a mountainous region. Quarterly Journal of 878 the Royal Meteorological Society, 135(639): 445-456.

879 Hajat, S; Ebi, KL; Kovats, S; Menne, B; Edwards, S; Haines, A; (2003) The human health 880 consequences of flooding in Europe and the implications for public health: a review of the 881 evidence. Applied Environmental Science and Public Health, 1: 13-21.

882 IACOW (1982) Guidelines for determining flood flow frequency. Bulletin 17B of the 883 Hydrology Subcommittee. US Geological Survey, Reston, VA.

884 Jasper, K., Gurtz, J. and Lang, H. (2002) Advanced flood forecasting in Alpine watersheds 885 by coupling meteorological observations and forecasts with a distributed hydrological 886 model. Journal of Hydrology, 267(1-2): 40-52.

887 Javelle, P., Fouchier, C., Arnaud, P. and Lavabre, J. (2010) Flash flood warning at 888 ungauged locations using radar rainfall and antecedent soil moisture estimations. Journal of 889 Hydrology, 394(1-2): 267-274.

890 Joss, J. and Waldvogel, A. (1990) Precipitation measurement and hydrology. In: D. Atlas 891 (Editor), Radar in Meteorology. Ed., American Meteorological Society, Boston (USA), pp. $892 \quad 577-606$.

893 Lavabre, J. and Gregoris, Y. (2006) AIGA: un dispositif d'alerte des crues. Application à la 894 région méditerranéenne française, Fifth FRIEND World Conference. IAHS, Havana, Cuba, 895 pp. 214-219.

896 Li, P.W. and Lai, E.S.T. (2004) Short-range quantitative precipitation forecasting in Hong 897 Kong. Journal of Hydrology, 288(1-2): 189-209. 
898 Lin, C., Vasi, S., Kilambi, A., Turner, B. and Zawadzki, I. (2005) Precipitation forecast

899 skill of numerical weather prediction models and radar nowcasts. Geophys. Research $900 \quad$ Letters, 32(14): L14801.

901 Liu, Y. , Weerts, A. H. , Clark, M. , Hendricks Franssen, H.-J. , Kumar, S., Moradkhani, H., 902 Seo, D.-J., Schwanenberg, D., Smith, P., van Dijk, A. I. J. M. , van Velzen, N., He, M., 903 Lee, H., Noh, S. J., Rakovec, O. and Restrepo, P. (2012) Advancing data assimilation in 904 operational hydrologic forecasting: progresses, challenges, and emerging opportunities. 905 Hydrology and Earth System Sciences, 16: 3863-3887

906 Meon, G. (2006) Past and present challenges in flash flood forecasting, First International 907 Workshop on Flash Flood Forecasting, San Jose, Costa Rica, pp. 2.

908 Merz, R. and Blöschl, G. (2009) A regional analysis of event runoff coefficients with 909 respect to climate and catchment characteristics in Austria. Water Resources Research, 910 45(1): W01405.

911 Michel, C., AndrÈassian, V. and Perrin, C. (2005) Soil Conservation Service Curve 912 Number method: How to mend a wrong soil moisture accounting procedure? Water Resour. 913 Res., 41(2): W02011.

914 Mockus, V. (1957) Use of storm and watersheds characteristics in synthetic hydrograph 915 analysis and application. Soil Conservation Service. U.S. Dept. of Agriculture, Washington 916 (USA).

917 MOPU (1990) Norma 5.2-IC, drenaje superficial: instrucción de carreteras. Ministerio de 918 Obras Públicas y Urbanismo, Dirección General de Carreteras, Madrid.

919 MOPU (1999) Máximas Lluvias de la España peninsular. Ministerio de Obras Públicas y 920 Urbanismo, Dirección General de Carreteras, Madrid.

921 Moulin, L., Gaume, E. and Obled, C. (2009) Uncertainties on mean areal precipitation: 922 assessment and impact on streamflow simulations. Hydrology and Earth System Sciences, 923 13(2): 99-114. 
924 Nash, J.E. and Sutcliffe, J.V. (1970) River flow forecasting through conceptual models part 925 I - A discussion of principles. Journal of Hydrology, 10(3): 282-290.

926 Norbiato, D., Borga, M., Degli Esposti, S., Gaume, E. and Anquetin, S. (2008) Flash flood 927 warning based on rainfall thresholds and soil moisture conditions: An assessment for 928 gauged and ungauged basins. Journal of Hydrology, 362(3-4): 274-290.

929 Norbiato, D., Borga, M., Sangati, M. and Zanon, F. (2007) Regional frequency analysis of 930 extreme precipitation in the eastern Italian Alps and the August 29, 2003 flash flood. 931 Journal of Hydrology, 345: 149-166.

932 Perrin, C., Michel, C., Andréassian, V. Does a large number of parameters enhance model 933 performance? Comparative assessment of common catchment model structures on 429 934 catchments. Journal of Hydrology, 242(3-4): 275-301.

935 Reed, S., Koren, V., Smith, M., Zhang, Z., Moreda, F., Seo, D.-J. and Participants, D. 936 (2004) Overall distributed model intercomparison project results. Journal of Hydrology, 937 298(1-4): 27-60.

938 Reed, S., Schaake, J. and Zhang, Z. (2007) A distributed hydrologic model and threshold 939 frequency-based method for flash flood forecasting at ungauged locations. Journal of 940 Hydrology, 337(3-4): 402-420.

941 Rossa, A., Bruen, M., Fruehwald, D., Macpherson, B., Holleman, I., Michelson, D. and 942 Michaelides, S. (2005) Use of Radar Observations in Hydrology and NWP models, 943 Brussels. 292 pp.,

944 Rozalis, S., Morin, E., Yair, Y. and Price, C. (2010) Flash flood prediction using an 945 uncalibrated hydrological model and radar rainfall data in a Mediterranean watershed under 946 changing hydrological conditions. Journal of Hydrology, 394(1-2): 245-255.

947 Sánchez-Diezma, R., Sempere-Torres, D., Delrieu, G. and Zawadzki, I. (2001) An 948 improved methodology for ground clutter substitution based on a pre-classification of 
949 precipitation types, 30th Int. Conf. on Radar Meteorology. Amer. Meteor Soc., Munich, 950 Germany, pp. 271-273.

951 Schiemann, R., Liniger, M.A. and Frei, C. (2010) Reduced space optimal interpolation of 952 daily rain gauge precipitation in Switzerland. J. Geophys. Res., 115(D14): D14109.

953 Sempere-Torres, D., Corral, C., Raso, J. and Malgrat, P. (1999) Use of weather radar for 954 combined sewer overflows monitoring and control. Journal of Environmental Engineering, 955 125: 372-380.

956 Siccardi, F., Boni, G., Ferraris, L. and Rudari, R. (2005) A hydrometeorological approach 957 for probabilistic flood forecast. Journal of Geophysical Research, 110: D05101.

958 Szymkiewicz, R. (2002) An alternative IUH for the hydrological lumped models. Journal of 959 Hydrology, 259(1-4): 246-253.

960 Tanguy, J.-M., Carriere, J.-M., le Trionnaire, Y. and Schoen, R. (2005) Réorganisation de 961 l'annonce des crues en France. La Houille Blanche, 2: 44-48.

962 Thielen, J., Bartholmes, J., Ramos, M.-H. and de Roo, A. (2009) The European Flood Alert 963 System - Part 1: Concept and development. Hydrology and Earth System Sciences, 13(2): $964 \quad 125-140$.

965 Todini, E. (1988) Rainfall-runoff modeling - Past, present and future. Journal of 966 Hydrology, 100(1-3): 341-352.

967 Van Der Knijff, J.M., Younis, J. and De Roo, A.P.J. (2010) LISFLOOD: a GIS-based 968 distributed model for river basin scale water balance and flood simulation. International 969 Journal of Geographical Information Science, 24(2): 189-212.

970 Velasco-Forero, C.A., Sempere-Torres, D., Cassiraga , E.F. and Gómez-Hernández, J.J. 971 (2009) A non-parametric automatic blending methodology to estimate rainfall fields from 972 rain gauge and radar data. Advances in Water Resources, 32: 986-1002. 
973 Versini, P.-A. (2012) Use of radar rainfall estimates and forecasts to prevent flash flood in

974 real time by using a road inundation warning system. Journal of Hydrology, 416-417: 157975170.

976 Versini, P.-A., Gaume, E. and Andrieu, H. (2010) Application of a distributed hydrological

977 model to the design of a road inundation warning system for flash flood prone areas.

978 Natural Hazards Earth System Sciences, 10(4): 805-817.

979 Versini, P.-A., Velasco, M., Cabello, A., Sempere-Torres D. (2013). Hydrological impact

980 of forest fires and climate change in a Mediterranean basin. Natural Hazards 66(20): 609981628.

982

983 Viviroli, D., Zappa, M., Gurtz, J. and Weingartner, R. (2009) An introduction to the 984 hydrological modelling system PREVAH and its pre- and post-processing-tools. 985 Environmental Modelling and Software, 24(10): 1209-1222.

986 Vivoni, E.R., Entekhabi, D., Bras, R.L., Ivanov, V.Y., Van Horne, M.P., Grassotti, C. and 987 Hoffman, R.N. (2006) Extending the Predictability of Hydrometeorological Flood Events 988 Using Radar Rainfall Nowcasting. Journal of Hydrometeorology, 7(4): 660-677.

989 Weeks, W.D. and Boughton, W.C. (1987) Tests of ARMA model forms for rainfall-runoff 990 modelling. Journal of Hydrology, 91(1-2): 29-47.

991 Wright, D.B., Smith, J.A., Villarini, G., Baeck, M.L. (2013) Estimating the frequency of 992 extreme rainfall using weather radar and stochastic storm transposition. Journal of 993 Hydrology. Article in Press.

994 Zappa, M., Beven, K.J., Bruen, M., Cofiño, A.S., Kok, K., Martin, E., Nurmi, P., Orfila, B., 995 Roulin, E., Schröter, K., Seed, A., Szturc, J., Vehviläinen, B., Germann, U. and Rossa, A. 996 (2010) Propagation of uncertainty from observing systems and NWP into hydrological 997 models: COST-731 Working Group 2. Atmospheric Science Letters, 11(2): 83-91. 
998 Zappa, M., Jaun, S., Germann, U., Walser, A. and Fundel, F. (2011) Superposition of three 999 sources of uncertainties in operational flood forecasting chains. Atmospheric Research, 1000 100(2-3): 246-262.

1001 Zawadzki, I. (1984) Factors affecting the precision of radar measurements of rain 1002 Conference on Radar Meteorology, 22nd. American Meteorological Society, Zurich, 1003 Switzerland, pp. 251-256.

1004

1005

1006 


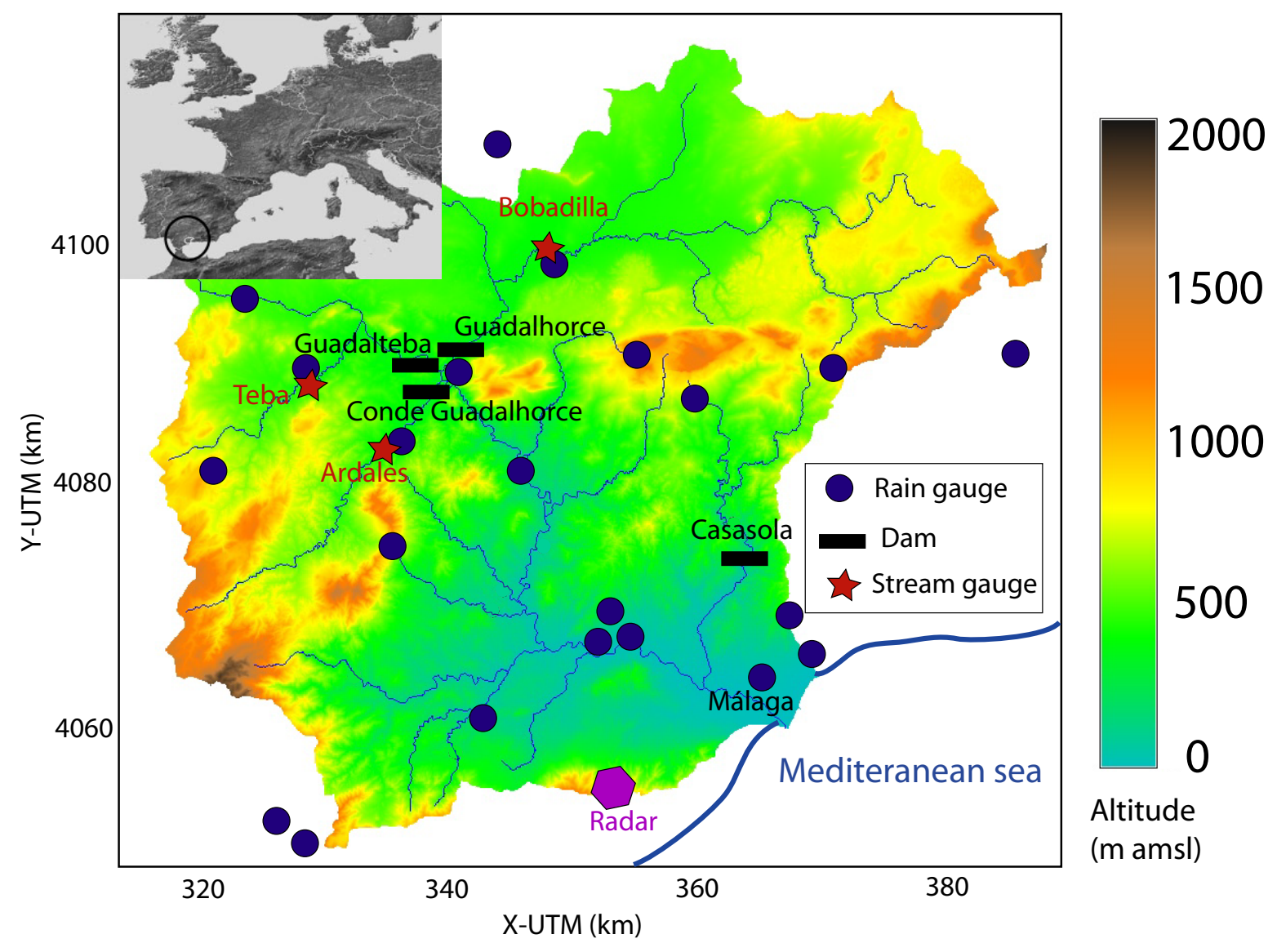

1009 Figure 1. The Guadalhorce basin and its hydro-meteorological sensors

1010
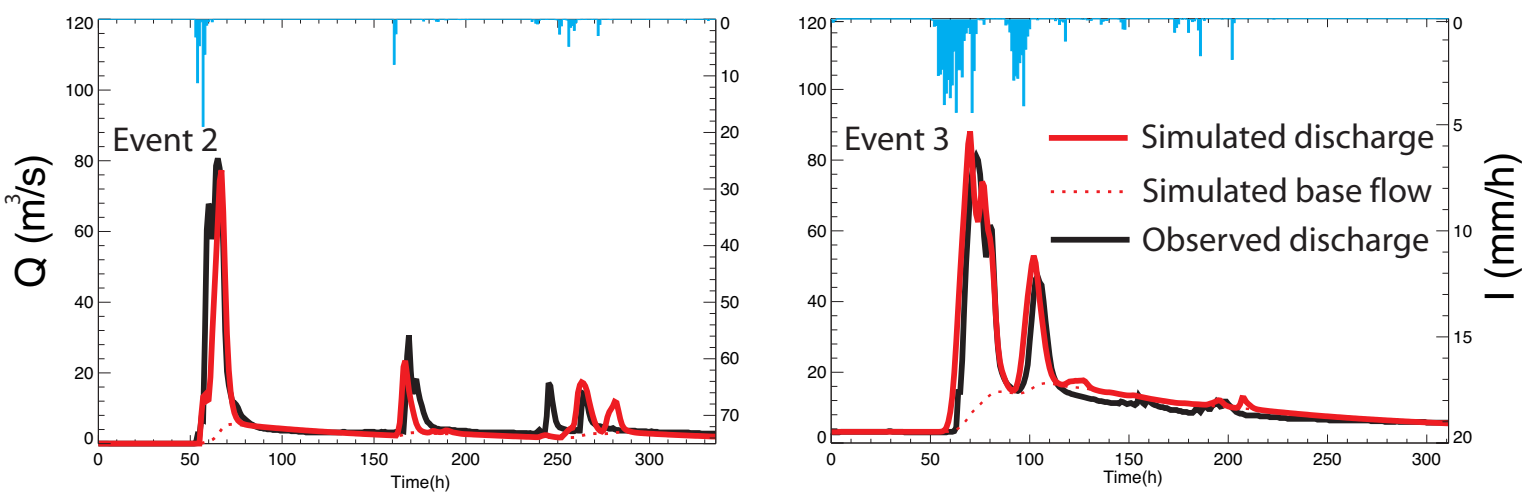

1012 Figure 2. Comparison between observed (black line) and simulated (red line) discharges on 1013 1014 Bobadilla basin. The left vertical axis represents the discharge (in $\mathrm{m} 3 / \mathrm{s}$ ). The right vertical axis represents the rainfall intensity (in $\mathrm{mm} / \mathrm{h}$ ). 


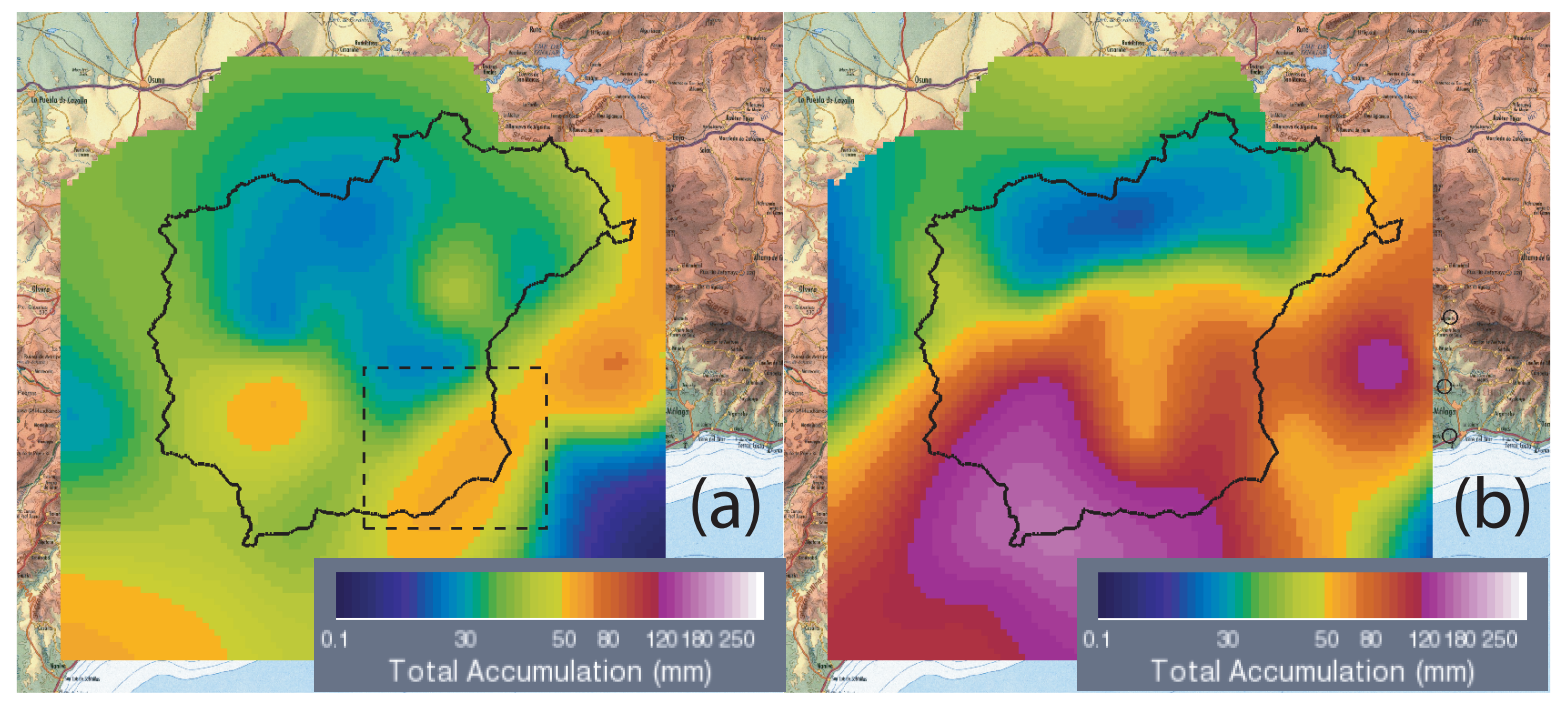

1017 Figure 3. Total estimated precipitation accumulation estimated from rain gauges for (a) 6-7 1018 January 2010, and (b) 15-16 February 2010.

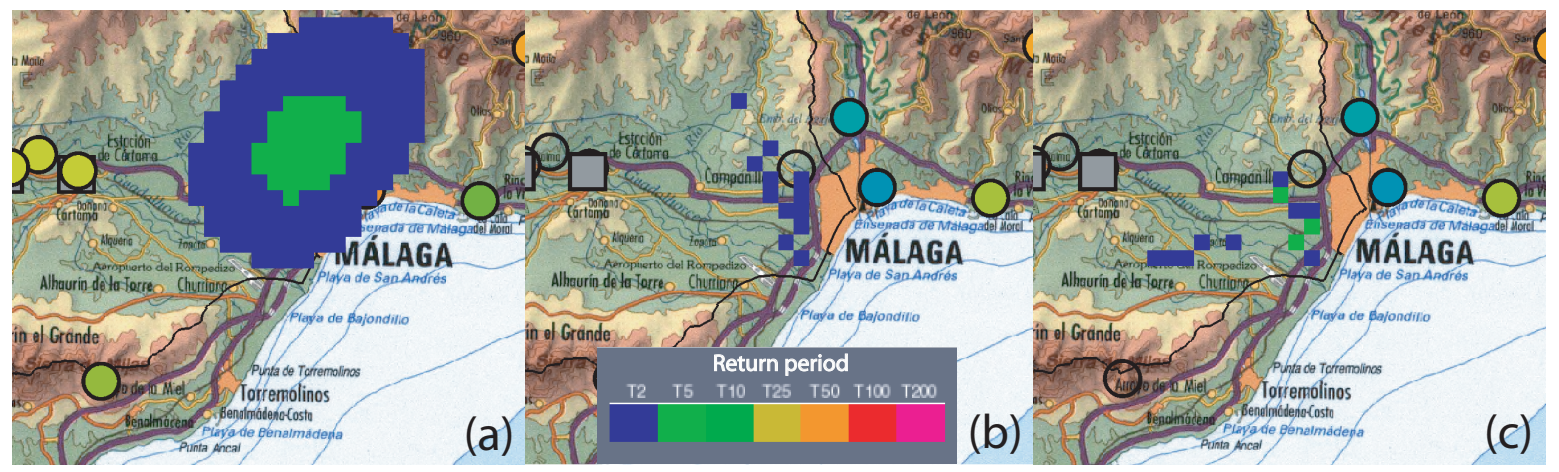

1021 Figure 4. Flood warnings issued on 7 January 2010 based on: (a) point rainfall at 9:00 1022 UTC, (b) aggregated rainfall at 10:00 UTC, and (c) simulated discharges at 10:00 UTC. 1023 This area around Málaga is the one defined by the dotted square in Fig. 3. The circles 1024 indicate the presence of the rain gauges. The solid red ellipses correspond to the effective 1025 flooding 


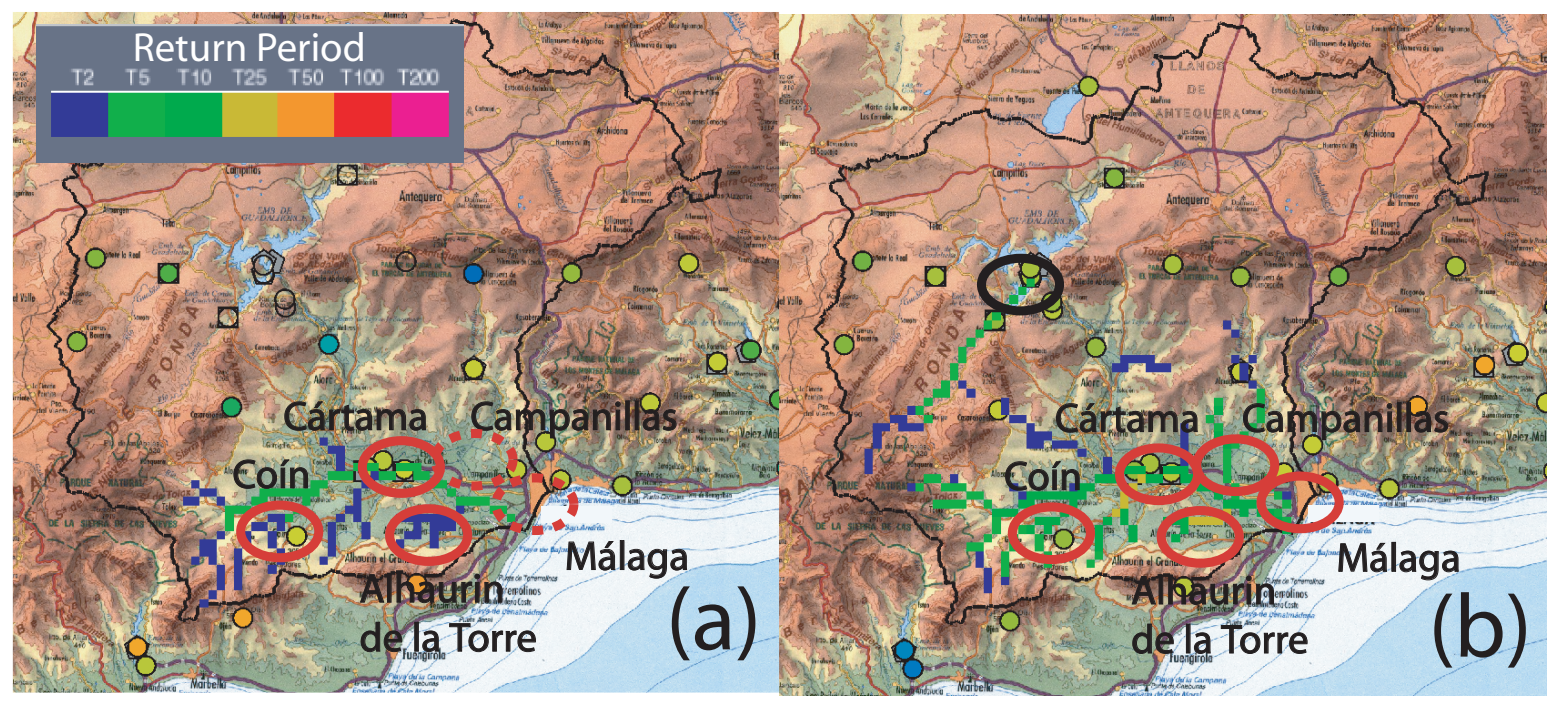

1028 Figure 5. Flood warnings issued on 16 February 2010 based on: (a) Aggregated rainfall at 1029 6:00, and (b) and simulated discharge at 7:00. Flooded locations are surrounded in red. The solid red ellipses correspond to the forecasted flooding and the dotted ellipses to the missed flooding. The black ellipse corresponds to the false alarm at Conde Guadalhorce dam.

(a)

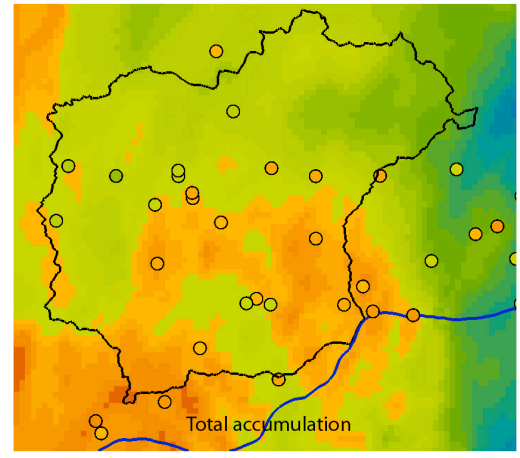

(b)

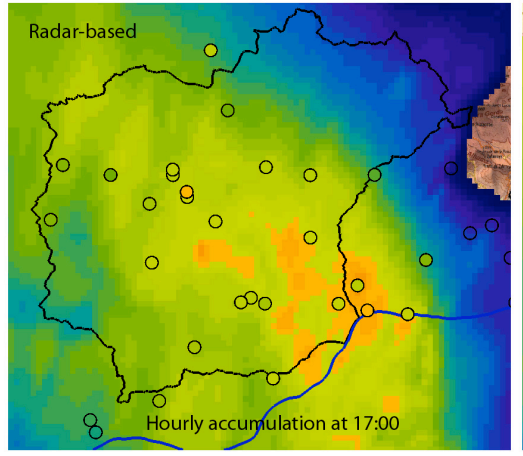

Precipitation $(\mathrm{mm})$

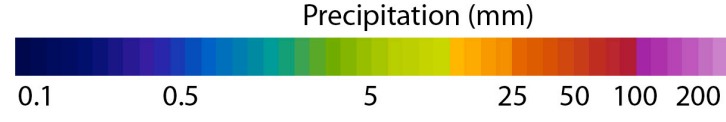

1034 Figure 6. Results obtained for the 21 April 2011 event: (a) total precipitation accumulated 1035 from radar-based estimates, (b) hourly rainfall field at 17:00 UTC computed by using radar1036 based estimates, (c) hourly rainfall field at 17:00 UTC interpolated from rain gauges. The 1038 circles represent the rain gauges and their observed values. 
1040 Table 1

1041

\begin{tabular}{|l|c|c|c|c|c|c|c|c|}
\hline & Event 1 & Event 2 & Event 3 & Event 4 & Event 5 & Event 6 & Event 7 & Event 8 \\
\hline Qmax [m 3 /s] & 44.4 & 80.7 & 81.2 & 27.2 & 20.8 & 42.6 & 22.7 & 84.3 \\
\hline Rainfall [mm] & 59.6 & 78.6 & 82.3 & 57.1 & 34.4 & 23.3 & 24.5 & 97.5 \\
\hline $\mathrm{NE}$ & -0.49 & 0.70 & 0.84 & -1.80 & -0.24 & 0.76 & 0.57 & 0.06 \\
\hline
\end{tabular}

1042 Table 1. Characteristics of the events selected for the calibration of the rainfall-runoff 1043 model in the Bobadilla watershed. In the table, Qmax is the maximum measured peak flow, 1044 Rainfall the total amount of precipitation on the sub-catchment, and NE the Nash efficiency 1045 characterizing the calibration assessment.

1046

1047 Table 2

\begin{tabular}{|l|c|c|c|c|c|c|}
\hline & \multicolumn{2}{|c|}{ Bobadilla } & \multicolumn{2}{c|}{ Teba } & \multicolumn{2}{c|}{ Ardales } \\
\hline Event & Qmax $\left[\mathrm{m}^{3} \mathrm{~s}^{-1}\right]$ & $\mathrm{NE}$ & Qmax $\left[\mathrm{m}^{3} \mathrm{~s}^{-1}\right]$ & $\mathrm{NE}$ & Qmax $\left[\mathrm{m}^{3} \mathrm{~s}^{-1}\right]$ & $\mathrm{NE}$ \\
\hline 6-7 January 2010 & 100 & 0.69 & 60 & 0.53 & - & - \\
\hline 15-16 February 2010 & 80 & 0.62 & 65 & 0.57 & 33 & 0.35 \\
\hline
\end{tabular}

1049 Table 2. Characteristics of test case studies and results obtained with the rainfall-runoff 1050 model at the gauged watersheds. In the table, Qmax is the maximum measured peak flow, and NE the Nash efficiency characterizing the calibration assessment. Note that, as 1053 explained in Section 3.3, Teba and Ardales gauges were not used in the calibration of the rainfall-runoff model. 